\title{
Optimization of Alkaline protease production by fungal isolate using solid state fermentation
}

\author{
Vaibhav Shinde, Nagesh Malik \\ (Department of Microbiology, V.E.S College of Arts, Science and Commerce, Chembur, Mumbai-400071, India)
}

\begin{abstract}
The purpose of the present study focuses on production of extracellular alkaline proteases by a local fungal isolate through solid state fermentation. The influence of process parameters such as solid substrates, incubation time, carbon and nitrogen source, inducers, activators and inhibitors $\mathrm{pH} \&$ temperature were studied. Wheat bran was found to be the best among the three solid substrates. The maximum protease production was seen at $120 \mathrm{~h}$ of incubation time. The protease production was increased when the medium was supplemented with Lactose as a carbon source. Among the different organic nitrogen sources investigated Yeast extract was found to produce maximum protease. Milk powder was found as the good inducer and EDTA was found as the protease inhibitor. The optimum $\mathrm{pH} \&$ temperature was 10 and $40^{\circ} \mathrm{C}$ respectively.
\end{abstract}

Keywords:Alkaline proteases, Milk powder, $\mathrm{pH}$, Solid state fermentation, Solid substrates

\section{Introduction}

Proteolytic enzymes account for nearly $60 \%$ of the industrial market and find applications in the number of biotechnological processes and pharmaceutical industry, leather industry, detergent industry etc. Such enzymes may be of commercial significance and hence, exploited to assist protein degradation in various industrial processes [1] [2] [3] [4]. Alkaline proteases hold a great potential for application in the detergent and leather industry due to the increasing trend to develop environment friendly technologies. Recently [5] reviewed production of Proteolytic enzymes in SSF systems. From their viewpoint, proteases produced by SSF have greater economic feasibility. In recent years, there have been increasing attempts to produce different types of proteases (acid, neutral \& alkaline) through SSF route, using agro-industrial residues. Alkaline proteases (E.C.3.4.21-24, 99) are defined as those proteases which are active in neutral to alkaline $\mathrm{pH}$ range. Alkaline proteases are generally produced by submerged fermentation. In addition solid state fermentation has been exploited to a lesser extent for production of these enzymes [2].Hence our focus will be on solid state fermentation. Different type of optimization process is carried out to get the maximum enzyme production.

\section{Materials \& Methods}

2.1 Isolation: Being a solid-state fermentation we were interested in isolating fungal organism. Samples collected from marshy soil and washing pond were domestic waste water is let out. Soil sample collected were inoculated in potato dextrose broth (PDB), broth was serially diluted and plated on Potato Dextrose Agar (PDA). The plates were then incubated at $30^{\circ} \mathrm{C}$ for $96 \mathrm{hr}$, observed fungal isolates were then re-isolated and was maintained on fresh PDA plates, which were used for further screening process.

2.2 Primary Screening: The isolates selected for further analysis were subjected to screening for their ability to produce the enzyme of interest. This was done by, selecting an organism which is capable of producing Proteolytic enzyme on sterile PDA containing 2\% skim milk as a protein source [6] [7] [8] .Visual observation for zone of clearance was used for detection of enzyme productivity by the isolates [9] [10] [11] [12] . Isolate which showed the maximum zone of clearance was used for further optimization study [13].

\section{Solid State Fermentation}

The media used for SSF includes; Wheat Bran 6g [14] [15] [16], Soybean meal 2g [2] [17] , Wheat flour 1g $[18,6 \mathrm{ml}$ salt solution with $80 \%$ total moisture level ( $6 \mathrm{ml}$ Salt solution $+2 \mathrm{ml}$ inoculum).

\section{Media Optimization}

Tooptimize the cultural conditions for maximum production of protease different parameters were studied, which includes; i) Effect of solid substrates, ii) Effect of incubation time, iii) Effect of carbon sources iv) Effect of nitrogen sources v) Effect of inducers vi) Effect of inhibitors and activators vii) Effect of $\mathrm{pH} \&$ viii) Effect of temperature. 


\subsection{Effect of solid substrates}

Solid substrates like Wheat bran, rice bran and rice husk were checked for the maximum production of alkaline protease as they are easily available at low cost. The best substrate which showed promising activity was selected. The selection of substrates for enzyme production in a SSF process depends upon several factors, mainly related to cost and availability of the substrate [19]

\subsection{Effect of incubation time}

Incubation time study was carried out to get maximum enzyme production $\left(2^{\text {nd }}, 3^{\text {rd }}, 4^{\text {th }} 5^{\text {th }} \& 6^{\text {th }}\right.$ day $)$

\subsection{Effect of carbon sources}

Various carbon sources were investigated for their effect on enzyme production. The carbon sources tested were fructose, dextrose, sucrose, lactose \& maltose. After completion of the incubation period, alkaline protease assay was carried out to determine the best carbon source for optimal enzyme production.

\subsection{Effect of nitrogen sources}

Alkaline protease production was investigated using different nitrogen sources like Yeast extract, peptone, beef extract soybean meal, one which gave the maximum enzyme production were used.

\subsection{Effect of inducers}

Various inducers were used to enhance enzyme production. Inducers used were highly proteinaceous, which includes Milk powder, Whey powder, \& Albumin powder.

\subsection{Effect of Activators and Inhibitors}

The effect of various Metal ions and chelators on enzyme production was checked. The compounds which increase the enzyme production, better known as activators, were added, whereas which negatively affected enzyme production was considered as inhibitors. Other inhibitors like EDTA (Ethylenediamine-tetraaceticacid), $\mathrm{AgNO}_{3} \& \mathrm{SDS}$ (Sodium Dodecyl sulphate) were also checked.

\subsection{Effect of $\mathrm{pH}$}

The effect of $\mathrm{pH}$ was studied ranging from $\mathrm{pH} 6.0-\mathrm{pH} 12$ to find out the optimum $\mathrm{pH}$, at which the enzyme is highly active. It was noted that, enzyme activity was in the increasing order from $\mathrm{pH} 6.0$ to $\mathrm{pH} 10$ and showed the maximum activity at pH 10 and activity declined marginally at pH 11 and pH 12 .

\subsection{Effect of temperature}

The enzyme activity was studied at different temperatures from $20^{\circ} \mathrm{C}-80^{\circ} \mathrm{C}$. The study determined which temperature helped to attain higher enzyme activity. The maximum activity was observed at $40^{\circ} \mathrm{C}$ and there was a slight drop in activity at $50^{\circ} \mathrm{C}$ and activity dropped drastically at $60^{\circ} \mathrm{C}, 70^{\circ} \mathrm{C} \& 80^{\circ} \mathrm{C}$.

\subsection{Effect of solid substrates}

\section{Results And Discussion}

Different substrates used to get maximum enzyme yield, like wheat ban, rice husk \& rice bran were studied, of the three solid substrates wheat bran gave good results as compared to rice bran and rice husk. (Fig. 1) [20] also got good results using Wheat Bran as the solid substrate. [21] also reported wheat bran as the good substrate.

\subsection{Effect of Incubation time}

Incubation time study was carried out by analyzing enzyme activity at $2^{\text {nd }}, 3^{\text {rd }}, 4^{\text {th }} 5^{\text {th }} \& 6^{\text {th }}$ day to determine the optimum enzyme production. Maximum enzyme production was seen on $5^{\text {th }}$ Day (i.e. 120h) (Fig. 2).

\subsection{Effect of carbon sources}

Different carbon sources were investigated to get the maximum enzyme production. Alkaline protease production was enhanced with $0.5 \%$ lactose as a carbon source. Other carbon sources failed to give promising results as compared to lactose (Fig.3). Increased yield of alkaline protease production were reported by several other researchers using different sugars such as Fructose, Dextrose, Sucrose, Lactose, Maltose. [22]

\subsection{Effect of Nitrogen sources}

Different nitrogen sources were screened, to check the maximum alkaline protease production and it was found that yeast extract and soyabean meal showed promising enzyme activity of all other nitrogen sources (Fig.4).

Similar observation was reported by [23]

\subsection{Effect of Inducers}

Highly proteinaceous inducers like Milk powder, Whey powder and Albumen powder were used to enhance the protease production, milk powder was found to be the excellent inducer (Fig. 5)

\subsection{Effect of Activators \& Inhibitors}

Various Metal ions and chelators were used to check the effect on enzyme production. $\mathrm{Ca}^{2+}$ enhanced the enzyme activity while EDTA acted as an inhibitor

[24] also reported protease inhibition using 1mM EDTA concentration.

\subsection{Effect of $\mathrm{pH} \&$ Temperature}

The effect of $\mathrm{pH} \&$ temperature was studied ranging from $\mathrm{pH} 6.0-\mathrm{pH} 12 \& 20^{\circ} \mathrm{C}-80^{\circ} \mathrm{C}$ respectively to find out the optimum $\mathrm{pH} \&$ temperature, at which the enzyme is highly active. It was noted that, enzyme activity was in the increasing order from $\mathrm{pH} 6.0$ to $\mathrm{pH} 10$ and showed the maximum activity at $\mathrm{pH} 10(265 \mathrm{u} / \mathrm{ml})$ and activity 
declined marginally at pH 11 and pH 12 as shown in (Fig. 6). As shown in (Fig. 7), It was found that enzyme activity increased according to the temperature, showed maximum activity at $40^{\circ} \mathrm{C}(268 \mathrm{u} / \mathrm{ml})$, there was decrease in activity seen at $50^{\circ} \mathrm{C}$, drastic drop in enzyme activity was seen at $60^{\circ} \mathrm{C} 70^{\circ} \mathrm{C} \& 80^{\circ} \mathrm{C}$. Effect of $\mathrm{pH}$ on Proteolytic activity was studied by [25] and it was noted that there was a drastic drop in activity at ${ }_{\mathrm{p}} \mathrm{H} 11$ and pH 12 instead of being isolated from alkaline habitat and $55^{\circ} \mathrm{C}$ as the optimum temperature. [26] also noted drop in enzyme activity as the ${ }_{\mathrm{PH}} \mathrm{H}$ increases. [7] noted $140 \mathrm{u} / \mathrm{ml}$ of the activity at $\mathrm{pH} 9$ and there was drastic drop in the activity at ${ }_{\mathrm{p}} \mathrm{H}$ more than 9 . Our enzyme is more alkali tolerant, as there is a marginal drop in the activity even at ${ }_{\mathrm{P}} \mathrm{H} 11$ and ${ }_{\mathrm{P}} \mathrm{H}$ 12. Protease activity at $40^{\circ} \mathrm{C}$ was also reported by [27]. Fungal proteases are usually thermo labile and show reduced activities at high temperatures [27]

\section{Figures \& Tables}

Fig. 1

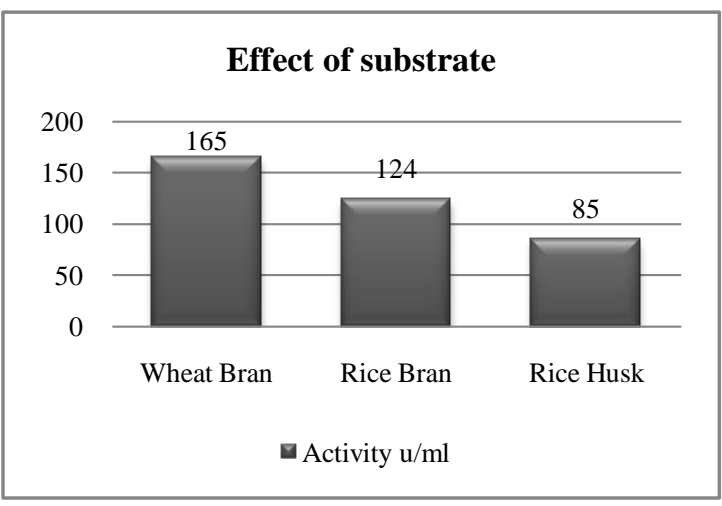

Fig.3

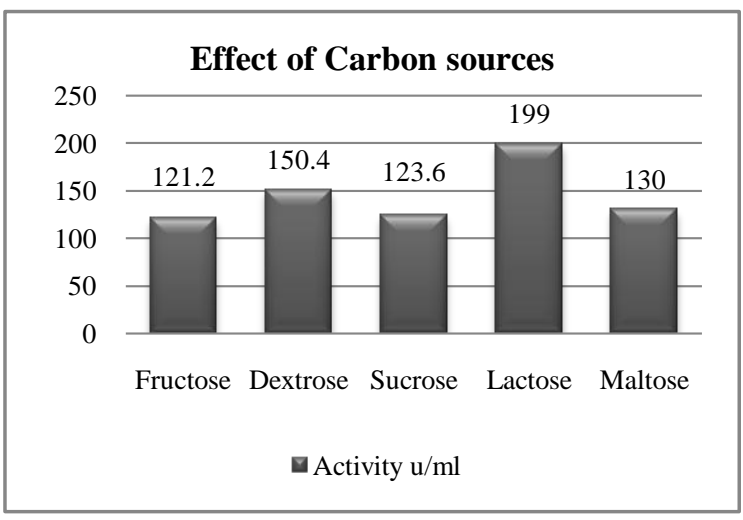

Fig. 5

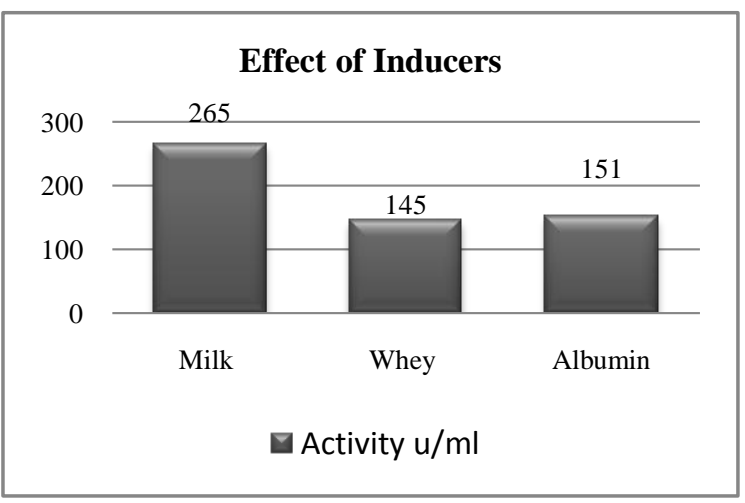

Fig. 2

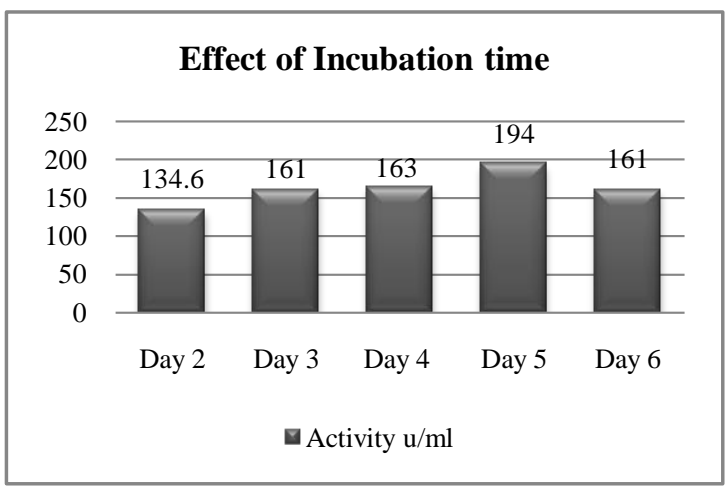

Fig.4

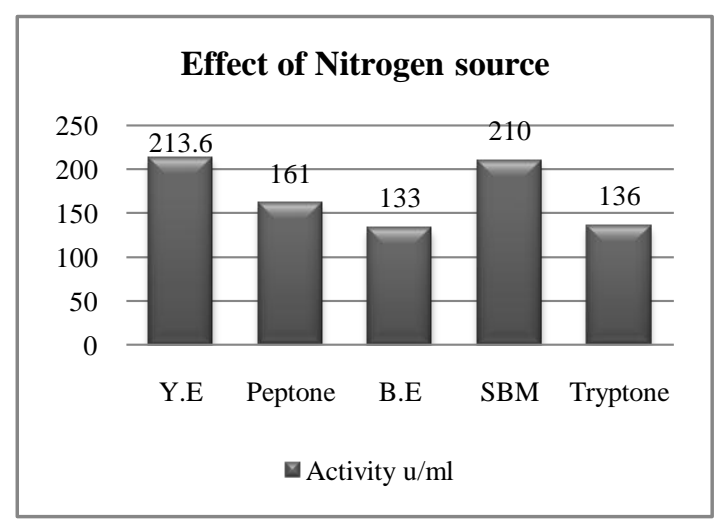

Fig. 6

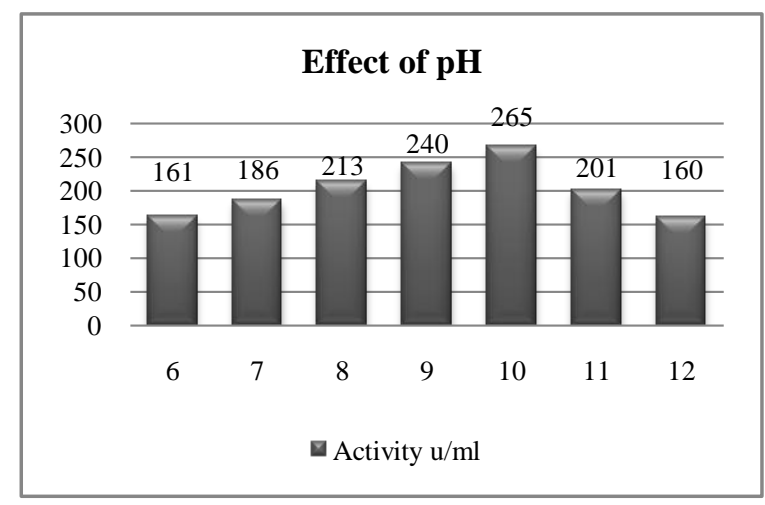


Fig. 7

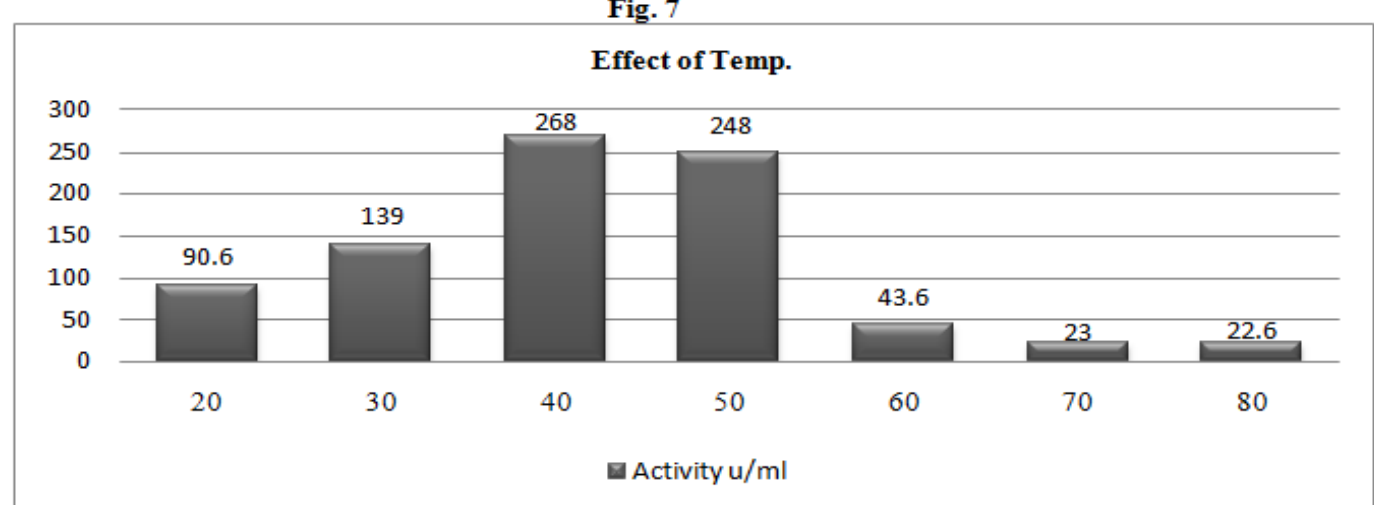

VII. Conclusion

Optimization of Alkaline protease production using solid state fermentation was carried out successfully. Wheat bran, proved to be a valuable substrate showing the maximum enzyme production. The organism is capable of producing a highly alkaline enzyme and thus can have a number of commercial applications.

\section{Acknowledgements}

The authors thank Dr Aruna Inamdar, Sr. Scientist, Chembond Chemicals Ltd, for her support and guidance. The authors also thank Dr J.K Phadnis, Principal, V.E.S College of Arts, Science and Commerce, for her support and encouragement.

\section{References}

[1] Phadatare S.U., D. V. (1993). High activity alkaline protease from Condiobolous coronatus(NCL86.8.20) Enzyme production and compatibility with commercial detergents. Enz. Microbiol. technol. , 15, 72-76.

[2] Rao M.B., T. A. (1998). Molecular and biotechnology aspects of microbial proteases. Microbiol. mol.Biol.Rev. , 62, 597-635.

[3] Kumar C.G., a. T. (1999). Microbial alkaline proteases: from a bio-industrial viewpoint. Biotechnol. Adv. , 17, 561-94.

[4] Gupta R., B. Q. (2002). Bacterial alkaline proteases: molecular approaches and industrial applications. Appl. Microbiol. Biotech. , 59, 15-32.

[5] Mitra P., C. R. (1994). Solid state fermentation. J. Sci. Ind. Res. , 55, 134-46,439-42.

[6] Kumar, D., \& Premavathi Venkatchalam, N. M. (2012). Production and purification of Alkaline Protease from Bacillus.sp.MPTK 712 isolated from Dairy sludge. IDOSI Publications , 51, 433-439.

[7] M. Sankareswaran, S. A. (2014). Optimization of production of an extracellular alkaline proteases by soil isolated Bacillus species using submerged and solid state fermentation with agricultural wastes. African Journal of Microbiology Research , 872-877.

[8] V.S.Kranthi, D. R. (2012). Protease production by Rhizopus stolonifer through solid state fermentation. Central European journal of Experimental Biology 1(3), 36, 113-117.

[9] Ten L.M., I. W. (2005). A plate assay for simultaneous screening of polysaccharide and protein degrading microorganisms. Lett. App. Microbiol , 40, 92-98.

[10] P., S. G. (1998). Selection of Optimal growth medium for the synthesis of alkaline proteinase from Bacillus SGP-26. J. Sci. Indus. Res. , 57, 629-33.

[11] Verma R., S. K. (2001). Solid state fermentation to produce alkaline protease by Aspergillus Fumigatus B149. Ind.J. Microbiol. , 41,111-14.

[12] Ellaiah P., A. K. Optimization of process parameters for alkaline protease production under solid state fermentation by alkalophilic Bacillus sp. Asian J. Microbiol. Biotechnol. Environ. Sci , 5, 49-54. 14

[13] Shinde, N. M. (2016). Comparative analysis of Alkaline Protease production by Solid state nd submerged production. International Journal of development and research , 6972-6976.

[14] H.M., K. (1988). Microbial proteinases. Adv. Biochem Eng Biotechnol. , 36, 1-65.

[15] Dr. Prasad A., W. Z. (n.d.). Production of mevastatin by SSF udsing wheat bran as a substrate. Bio process Engineering and technology

[16] A.L., M. P. (n.d.). Solid state fermentation. 134-36.

[17] SRIVIDYA, S., \& MALA, M. (2011). Influence of process parameters on the production of detergent compatible alkaline proteases by a newly isolated Bacillus sp.Y. Turkish Journal of Biology, 177.

[18] Ashok Pandey, P. S. (n.d.). Solid State Fermentation for the production of industrial enzymes.

[19] Patil, V. M. (1999). Production of Proteases by Aspergillus flavus under Solid state fermentation . International Journal of experimental biology , 1248-1250.

[20] Chinnasamy Muthulakshmi, D. G. (2011). Production, Purification and Characterization of Proteases by Aspergillus flavus solid state fermentation. Jordan Journal of Biological sciences, 137-148.

[21] Chakrabartty, P. a. (2005). An extracellular protease with depilation activity from Streptomyces nogalator. Journal of scientific and Industrial Research , 978-983.

[22] P.Palanivel, L. A. (2013). Production, Purification and Fibronolytic characterization of Alkaline protease form extremophilic soil fungi. International Journal of Pharma and Bioscience, 4 (2) : (B) 101-110.

[23] Mitra P., C. R. (1994). Solid state fermentation. J. Sci. Ind. Res. , 55, 134-46,439-42.

[24] Pathak., M. G. (2014). Isolation and identification of Alkaline Protease production from selected Alkaline Habitat. International journal of innovative biological research Vol 3; Issue 1, 12(2), 1-6. 
[25] K. Krishnaveni, D. K. (2012). Production and optmization of extracellular Alkaline Protease from Bacillus subtilis from Dairy Effluent. Scholar Research Library 4(1) , 45(2), 98-109.

[26] M.Sankareswaran, \& s. Anbalagan, a. P. (Feb 2014). Optimization of production of an extracellular alkaline protease by soil isolated bacillus sp. using submerged and solid state fermentation with agricultural wastes. African Journal of Microbiology Research Vol (8) , 4, 872-877.

[27] V.S.Kranthi, D. R. (2012). Protease production by Rhizopus stolonifer through solid state fermentation. Central European journal of Experimental Biology 1(3) , 36, 113-117. 